\title{
A remarkable new species of Phocides (Lepidoptera: Hesperiidae) from Bolivia and taxonomic considerations on Phocides charon
}

\author{
Ricardo R. Siewert (D), Gabriela L. Leviski (D), Olaf H. H. Mielke (D) \& Mirna M. Casagrande (i) \\ Laboratório de Estudos de Lepidoptera Neotropical, Departamento de Zoologia, Setor de Ciências Biológicas, Universidade Federal do Paraná, \\ Caixa Postal 19020, 81531-980 Curitiba, PR, Brasil. (ricardo.siewert@gmail.com)
}

\author{
Received 06 November 2017 \\ Accepted 14 May 2018 \\ Published 25 June 2018 \\ DOI $10.1590 / 1678-4766 e 2018023$
}

ABSTRACT. A new skipper butterfly, Phocides petroleum Siewert, Leviski, Mielke \& Casagrande sp. nov. is described and illustrated from Caranavi, La Paz Department, Bolivia. The new species seems closely related to Phocides charon (C. Felder \& R. Felder, 1859) but could be easily distinguished by a set of external characteristics. Lectotypes are designated for Erycides charon C. Felder \& R. Felder, 1859 and Erycides scython Godman \& Salvin, 1879.

KEYWORDS. Butterfly, Eudaminae, Neotropical, systematic, taxonomy.

Among the seven subfamilies recognized in Hesperiidae, Eudaminae stands out with over 110 species allocated in 17 genera distributed on Neotropics (with exception of the Asian genus Lobocla Moore, 1884) (WARREN et al., 2009, 2017). Although no morphological synapomorphy has been recognized yet, Eudaminae was recently treated as a subfamily separated from Pyrginae (WARren et al., 2009; SAHOO et al., 2016, 2017). The adults can be partly characterized by the long forewing discal cell and by the long hind wings, produced at the tornus, with the dorsum longer than the abdomen (WARREN et al., 2009). However the generic relationships within the most Eudaminae are poorly resolved, and futures studies are encouraged to be conducted to improve the knowledge of their relationships.

Phocides Hübner, [1819] is a notorious genus of Eudaminae with 18 described species characterized mostly by the blue, white and black wing pattern (MielKe, 2005). The genus is part of a large and complex mimicry system together with Tarsoctenus Watson, 1893 (Eudaminae) and the pyrrhopygines Elbella Evans, 1951, Granila Mabille, 1903, Jemadia Watson, 1893, Parelbella Mielke, 1995, Protelbella Mielke, 1995, and Zonia Evans, 1951.

Two specimens of Phocides from Bolivia closely related to Phocides charon (C. Felder \& R. Felder, 1859) drew our attention due its remarkable wing pattern during the study of Eudaminae from the Olaf Mielke collection in Coleção Entomológica Pe. Jesus Santiago Moure of the
Departamento de Zoologia of Universidade Federal do Paraná, Brazil (DZUP-OM). With the aim to contribute to the knowledge of the Neotropical biodiversity of Hesperiidae, this paper describes a new species of Phocides from Caranavi, La Paz, Bolivia, and provides taxonomic considerations on $P$. charon and on its associated synonyms.

\section{MATERIAL AND METHODS}

The specimens dissected had their abdomens detached and soaked in a heated $10 \%$ potassium hydroxide solution $(\mathrm{KOH})$ for about 5-10 minutes. The genitalia was removed and its structures were analyzed and illustrated with the aid of a camera lucida attached to a stereoscopic microscope. The dissected parts were kept in vials with glycerin. For the morphological study, the terminology follows CARNEIRo et al. $(2012,2013)$. The specimens dissected are indicated with an asterisk and in 'Type Material' section the labels are separated by ' $/$.

All specimens studied are from the Olaf Mielke collection in Padre Jesus Santiago Moure collection, Departamento de Zoologia, Universidade Federal do Paraná, Curitiba, Paraná, Brazil (DZUP-OM), Natural History Museum, London, United Kingdom (NHMUK), Zoologische Staatssammlung München, München, Germany (ZSM), and Museum für Naturkunde Leibniz-Institut für Evolutions und Biodiversitätsforschung an der Humboldt-Universität zu Berlin, Germany (ZMHU). 


\section{RESULTS}

\section{Phocides petroleum Siewert, Leviski, Mielke \& Casagrande sp. nov.}

(Figs 1, 2, 5, 7)

urn:lsid:zoobank.org:act:DD2FB6E0-0DFD-4F43-9E81CF8E58293844

Diagnosis. Phocides petroleum sp. nov. resembles $P$. charon (Figs 3, 4, 6) externally, but differing from the latter by the whitish blue patch from costa to the middle of discal cell on the underside of forewings, the whitish blue patch at basal area from costa to $2 \mathrm{~A}$ on the underside of hind wings, the absence of yellow fringes on the tornus of hind wings, and the deepest serrated distal margin of uncus.

Description. Head: dark brown, frons covered by dark brown and whitish blue scales; antenna dark brown, nudum 37-38 ( $\mathrm{n}=2)$; labial palpus dark brown, base of first segment mixed with dark brown and whitish blue scales
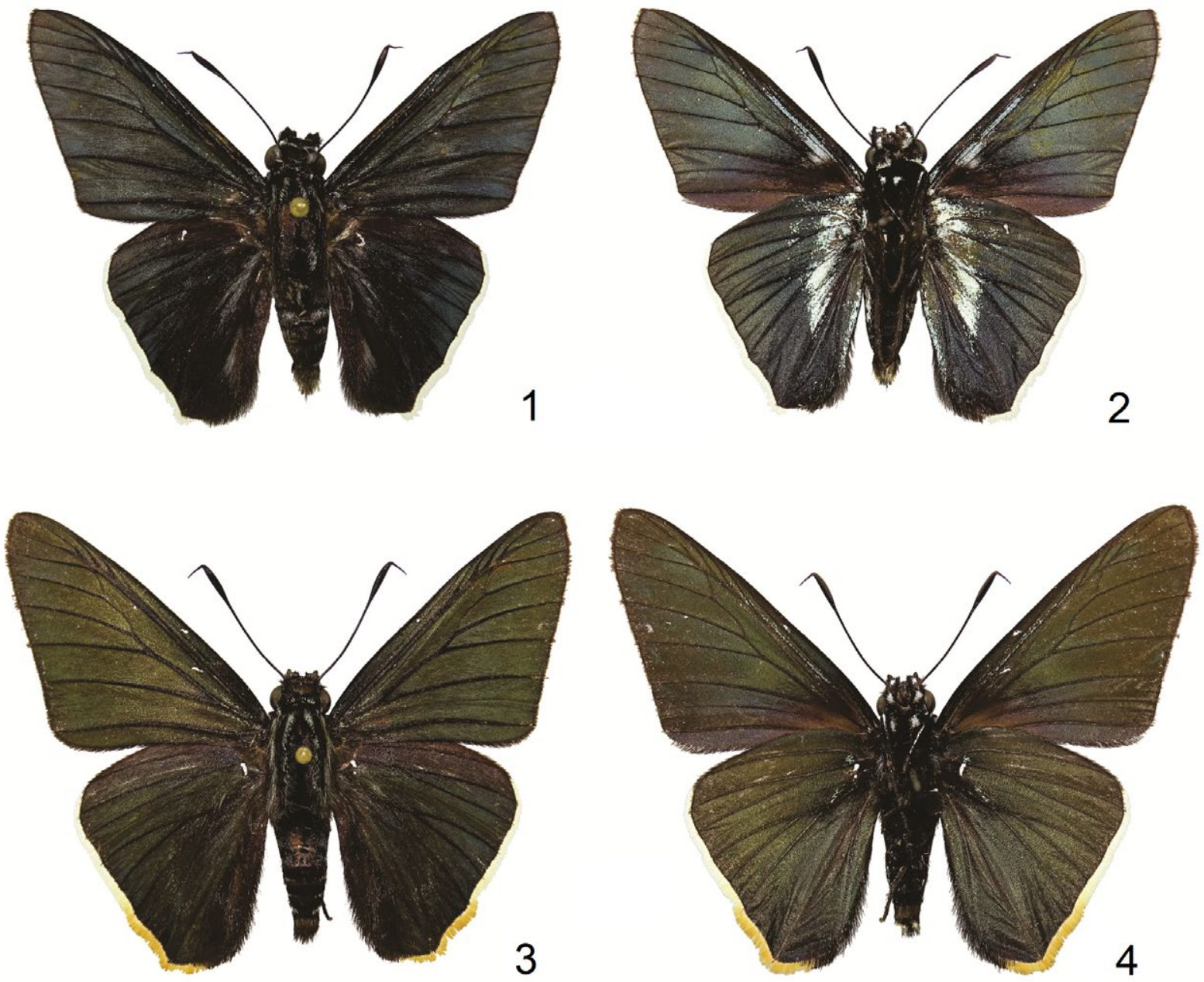

\section{$1 \mathrm{~cm}$}

Figs 1-4. Habitus of Phocides species. Figs 1, 2, Phocides petroleum sp. nov., holotype, in dorsal (1) and ventral (2) views; Figs 3, 4, Phocides charon (C. Felder \& R. Felder, 1859) in dorsal (3) and ventral (4) views. 

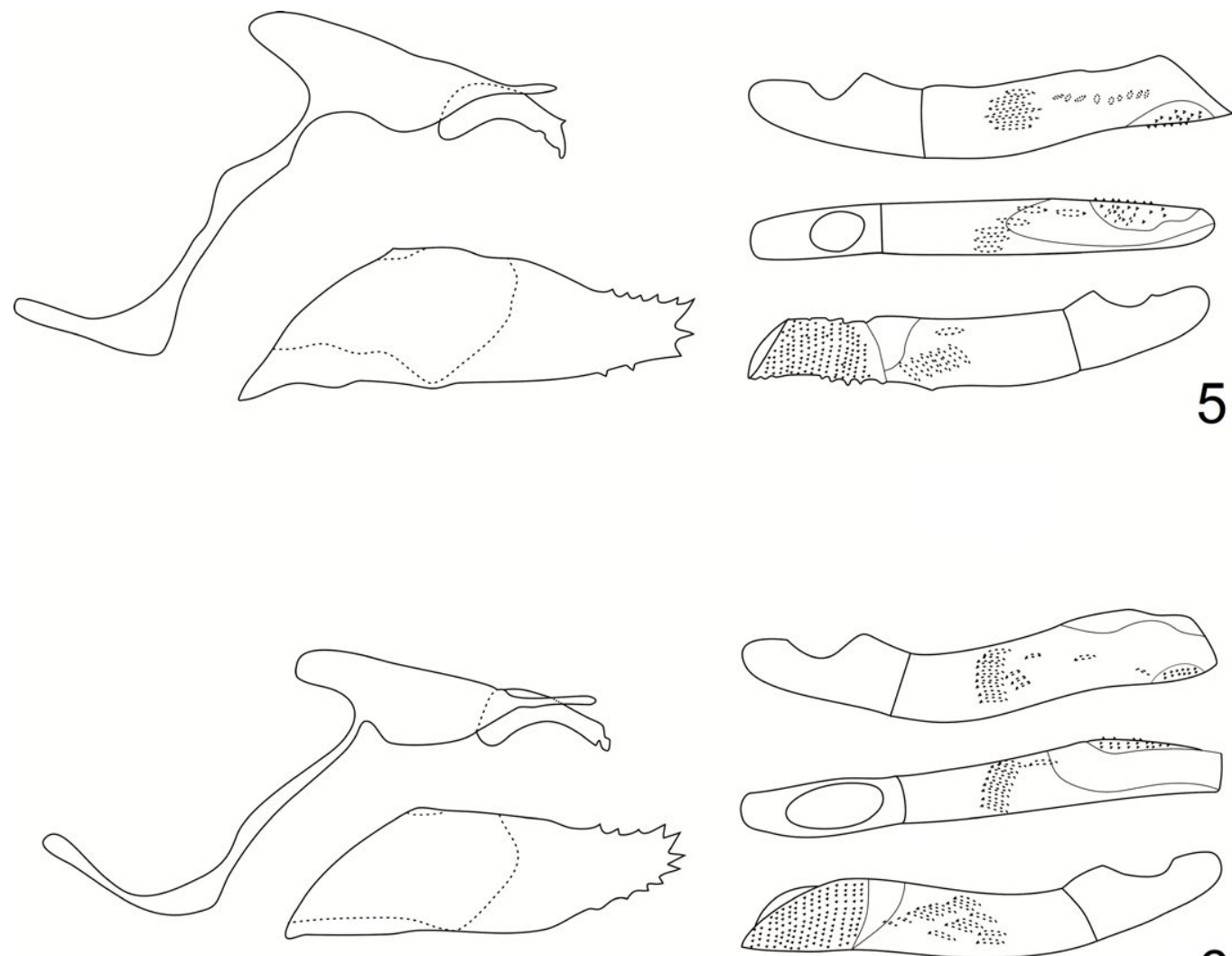

6

\section{$1 \mathrm{~mm}$}

Figs 5, 6. Male genitalia of Phocides species: tegumen and uncus in lateral view; valva in external view; aedeagus in left, dorsal and right views: Fig. 5, Phocides petroleum sp. nov.; Fig. 6, Phocides charon (C. Felder \& R. Felder, 1859) from Villarica, Paraguay (DZ 39.712).



Fig. 7. Distribution of Phocides petroleum sp. nov. and P. charon (C. Felder \& R. Felder, 1859). 
wide; distal margin deeply serrated. Aedeagus thick; coecum rounded; opening for ejaculatory bulb ovoid; third distal portion of aedeagus covered by small spines; distal opening of aedeagus dorsal; cornuti as numerous spines.

Female remains unknown.

Type Material. Holotype. $\widehat{\delta}$ from Caranavi, La Paz Departament, Bolivia, deposited at DZUP-OM with the following labels: /HOLOTYPUS/ VIII-1989 CARANAVI BOLÍVIA, 600-1000 m C. Tello leg./ OM 23.853/ HOLOTYPUS Phocides petroleum Siewert, Leviski, Mielke \& Casagrande/. Paratype $\widehat{\jmath}$. BOLIVIA: La Paz-Caranavi Area, 1100-2100 m, XII-2012-I-2013, C. Tello leg., OM 61.335* (DZUP-OM).

Etymology. This species is named after the beer Dum Petroleum. The Dum is an Brazilian brewery located in Curitiba, Paraná, funded in July 2010. The name is also in reference to the iridescent dark cobalt blue of wings, resembling the petroleum.

Distribution. Phocides petroleum sp. nov. is known only from its type locality.

\section{DISCUSSION}

Phocides petroleum sp. nov. is easily distinguished from $P$. charon by its external morphology. Until now, $P$. petroleum sp. nov. is known only from Caranavi, La Paz, Bolivia while $P$. charon has its occurrence recorded in several Southeast (Minas Gerais and São Paulo) and South Brazilian states (Paraná, Santa Catarina and Rio Grande do Sul), Uruguay (SCHWEIZER \& KAY, 1941), Argentina (Chaco and Misiones) (HaYward, 1973), and Paraguay (Tab. I, Fig. 7). The record from Peru reported by DRAUDT (1921) is probably wrong.

Concerning the morphology of male genitalia, Phocides seems to follow a known pattern for many Eudaminae: the similarity of this structure even in not closely related species (Grishin, 2013). This is also the case of $P$. petroleum sp. nov. when compared to $P$. charon, possibly its closest ally, and also with other species from the genus (Evans, 1952). The taxonomy of some Eudaminae could be difficult by the presence of many criptic species, and an integrative approach (e.g. B̈̈CHTOLD et al., 2017) is a highly recommended tool to better understand the true diversity of Neotropical skippers.

Taxonomic considerations on Phocides charon. Phocides charon has currently two synonyms: Erycides scython Godman \& Salvin, 1879 described from Paraguay, without mentioning a specific locality, and Erycides tophana Plötz, 1879 described from Minas Gerais, Brazil. The former was synonymized in $P$. charon by Evans (1952) while the

Tab. I. Geographical records of Phocides charon (C. Felder \& R. Felder, 1859).

\begin{tabular}{|c|c|c|c|}
\hline Country & State/Province & Municipality & Locality \\
\hline Argentina & Chaco & & No specific locality \\
\hline Argentina & Misiones & Concepción de la Sierra & \\
\hline Argentina & Misiones & Dos de Mayo & \\
\hline Argentina & Misiones & General Belgrano & Almirante Brown, Reserva Yacutinga \\
\hline Argentina & Misiones & Puerto Iguazú & \\
\hline Brazil & Minas Gerais & Conceição dos Ouros & \\
\hline Brazil & Paraná & & $12,5 \mathrm{~km} \mathrm{~N}$ de Ventania \\
\hline Brazil & Paraná & & Rio das Cobras \\
\hline Brazil & Paraná & Foz do Iguaçu & \\
\hline Brazil & Paraná & Guararuava & Santa Clara \\
\hline Brazil & Paraná & Lapa & Fazenda Uru \\
\hline Brazil & Paraná & Marechal Cândido Rondon & Vila Mercedes \\
\hline Brazil & Paraná & Matelândia & \\
\hline Brazil & Paraná & Monte Castelo & \\
\hline Brazil & Paraná & Ponta Grossa & \\
\hline Brazil & Paraná & Prudentópolis & Reserva Particular do Patrimônio Natural Ninho do Corvo \\
\hline Brazil & Paraná & São Miguel do Iguaçu & Parque Nacional do Iguaçu \\
\hline Brazil & Paraná & Terra Rica & Parque Nacional Três Morrinhos \\
\hline Brazil & Paraná & Tibagi & \\
\hline Brazil & Rio Grande do Sul & Guarani das Missões & \\
\hline Brazil & Rio Grande do Sul & São Luis Gonzaga & \\
\hline Brazil & Santa Catarina & Ibirama & Barra do Prata \\
\hline Brazil & Santa Catarina & São Bento do Sul & Rio Natal \\
\hline Brazil & São Paulo & Araçatuba & \\
\hline Brazil & São Paulo & Indiana & \\
\hline Brazil & São Paulo & Presidente Venceslau & \\
\hline Brazil & São Paulo & Rio Paraná & Porto Cabral \\
\hline Brazil & São Paulo & Teodoro Sampaio & Parque Estadual Morro do Diabo \\
\hline Paraguay & [Guairá] & Villarica & \\
\hline Uruguay & & & No specific locality \\
\hline
\end{tabular}


latter was synonymized by HAYWARD (1933). The examination of the type material of $P$. charon and its synonyms led us to describe P. petroleum sp. nov. and designate lectotypes for Erycides charon C. Felder \& R. Felder, 1859 and E. scython.

Erycides charon was described based an unknown number of male specimens from Brazil. The species was reallocated in Phocides by DRUCE (1908). After studying the type material of the Felder collection deposited at NHMUK, one syntype male of $E$. charon from Brazil was found. To provide stability to the name proposed by C. Felder \& R. Felder, this specimen is hereby designated as the lectotype. The male lectotype is illustrated in the Butterflies of America website (WARREN et al. 2017), and has the following labels: /Type / Type H T [verse of the same label: H 12 1] / 310 / Brazil merid Type / Felder Coll n. / Erycides charon Feld / charon $\mathrm{n}$. / Rothschild Bequest B. M. 1939-1/. The following labels will be added: /LECTOTYPUS / Lectotype Erycides charon C. Felder \& R. Felder, 1859 Siewert, Leviski, Mielke $\&$ Casagrande/.

Erycides scython was described without mention the number of specimens from Paraguay collected by Keith Johnson. After studying the Godman \& Salvin type collection deposited at the NHMUK, one syntype male from Paraguay collected by Keith Johnson was found. To provide stability to the name proposed by Godman \& Salvin, this specimen is hereby designated as the lectotype of Erycides scython. The male lectotype is illustrated in the Butterflies of America website (WARREN et al., 2017), with the following labels: /Type H T [verse of the same label: H 12 2] / Paraguay.

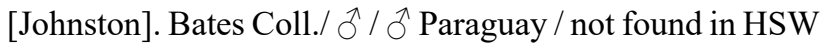
coll. 1879 / Erycides scython Type G. \& S. / Godman-Salvin Coll. 1912.-23. Phocides tophana Plotz./. The following labels will be added: /LECTOTYPUS / Lectotype Erycides scython Godman \& Salvin, 1879 Siewert, Leviski, Mielke \& Casagrande/.

Erycides tophana was described based on a single specimen [holotype] from Minas Gerais, Brazil (carrying a label with the number 4943). The holotype is deposited at the ZMHU and has the following labels: /Lectotypus [should be Holotypus] / Type / 4943 / Minas V. Olf / tophana Pl. Type/. In ZSM there is another male specimen with the following labels: /Original / Brasil; S.[ão] Paulo / Phocides tophana Pl. Bras. / Erycides tophana Plötz / Paralectotypus Erycides tophana Plötz, 1879, Zool. Staatssammlg. München, O. Mielke det. 1979/. The 'Lectotypus' and 'Paralectotypus' labels were mistakenly added in these specimens by Olaf Mielke during his visit in these collections in 1970s. Plötz used to mention the exact number of specimens (through the codes) which was used to describe his species, therefore these labels should not be interpreted as true lectotypes and paralectotypes.
Acknowledgements. We are grateful to Richard I. Vane-Wright (NHMUK), Phillip R. Ackery (NHMUK), Hans-Joachim Hannemann (in memorian; ZMHU), Wolfram Mey (ZMHU), Walter Forster (in memorian; ZSM) and Wolfgang Dierl (in memorian; ZSM) for providing access to specimens in the referred collection. The authors are also grateful to the Conselho Nacional de Desenvolvimento Científico e Tecnológico (CNPq) for the following research fellowships: R.R.S. (150360/2017-7), G. L. L. (142304/2015-8), O.H.H.M. (304639/2014-1) and M.M.C. (308247/2013-2).

\section{REFERENCES}

Bächtold, A.; Kaminski, L. A.; Magaldi, L. M.; Oliveira, P. S.; DelClaro, K.; Janzen, D. H.; Burns, J. M.; Grishin, N.; HaJibabaei, M.; Hallwachs, W. \& Freitas, A. V. L. 2017. Integrative data helps the assessment of a butterfly within the Udranomia kikkawai species complex (Lepidoptera: Hesperiidae): Immature stages, natural history, and molecular evidence. Zoologischer Anzeiger 266:169-176.

Carneiro, E.; Mielke, O. H. H. \& Casagrande, M. M. 2012. Head morphology of some Neotropical Hesperiidae (Lepidoptera). Zootaxa 3198:1-28.

Carneiro, E.; Mielke, O. H. H. \& Casagrande, M. M. 2013. Thorax and abdomen morphology of some Neotropical Hesperiidae (Lepidoptera). Insecta Mundi 327:1-47.

Draudt, M. W. K. 1921. Grypocera, breitköpfige Tagfalter. In: SEITZ, A. ed. Die Gross-Schmetterlinge der Erde. V.5, Stuttgart, Alfred Kernen, p. 844-856.

Druce, H. H. 1908. Description of some new Hesperiidae from Central and South America. Transactions of the entomological Society of London 1908(2):375-386.

Evans, W. H. 1952. A catalogue of the American Hesperiidae indicating the classification and nomenclature adopted in the British Museum (Natural History). Part II. Pyrginae. Section I. London, British Museum (Natural History). v $+178 p$.

Grishin, N. 2013. A new Entheus (Hesperiidae: Eudaminae) from Colombia and Panama is most distinctive in the E. gentius group. The Journal of Research on the Lepidoptera 46:91-103.

HAYwARD, K. J. 1933. Lepidópteros argentinos. Familia Hesperidae. Revista de la Sociedad Entomológica Argentina 5(3):149-188.

HaYward, K. J. 1973. Catálogo de los ropalóceros argentinos. Opera Lilloana 23:1-318.

MielKe, O. H. H. 2005. Catalogue of the American Hesperioidea. Vols 1-6. Curitiba, Sociedade Brasileira de Zoologia. 1536p.

Sahoo, R. K.; Warren, A. D.; Collins, S. C. \& Kodandaramaiah, U. 2017. Hostplant change and paleoclimatic events explain diversification shifts in skipper butterflies (Family: Hesperiidae). BMC Evolutionary Biology 17:174.

Sahoo, R. K.; Warren, A. D.; Wahlberg, N.; Brower, A. V. Z.; Lukhtanov, V. A. \& Kodandaramaiah, U. 2016. Ten genes and two topologies: an exploration of higher relationships in skipper butterflies (Hesperiidae). PeerJ 4:e2653.

SChweIzer, F. \& Kay, R. G. W. 1941. Lepidópteros del Uruguay. II. Catálogo sistemático. Parte I. Rhopalocera \& Grypocera. Anales del Museo de Historia Natural de Montevideo (2)5(3): 1-24.

Warren, A. D.; Ogawa, J. R. \& Brower, A. V. Z. 2009. Revised classification of the family Hesperiidae (Lepidoptera: Hesperioidea) based on combined molecular and morphological data. Systematic Entomology 34:467-523.

Warren, A. D.; Davis, K. J.; Stangeland, E. M.; Pelham, J. P. \& Grishin, N. V. 2017. Illustrated Lists of American Butterflies. Available at $<$ http:// www.butterfliesofamerica.com/>. Accessed on 22 September 2017. 